\title{
Interactive comment on "Distributed snow and rock temperature modelling in steep rock walls using Alpine3D" by A. Haberkorn et al.
}

A. Haberkorn et al.

haberkorn@slf.ch

Received and published: 31 August 2016

The comment was uploaded in the form of a supplement:

http://www.the-cryosphere-discuss.net/tc-2016-73/tc-2016-73-AC2-supplement.pdf

Interactive comment on The Cryosphere Discuss., doi:10.5194/tc-2016-73, 2016. 